\title{
Frank Capra and Elia Kazan, American outsiders
}

\section{Yves Carlet}

\section{(2) OpenEdition}

\section{Journals}

\section{Electronic version}

URL: https://journals.openedition.org/ejas/8766

DOI: $10.4000 /$ ejas. 8766

ISSN: 1991-9336

\section{Publisher}

European Association for American Studies

\section{Electronic reference}

Yves Carlet, "Frank Capra and Elia Kazan, American outsiders", European journal of American studies [Online], 5-4 | 2010, document 6, Online since 15 November 2010, connection on 08 July 2021. URL: http://journals.openedition.org/ejas/8766 ; DOI: https://doi.org/10.4000/ejas.8766

This text was automatically generated on 8 July 2021

Creative Commons License 


\title{
Frank Capra and Elia Kazan, American outsiders
}

\author{
Yves Carlet
}

"I lived close to L.A. High, but since I belonged to
the riff-raff of Dagos, Shines, Cholos, and Japs, I
was sent out to swell the opening of 'Siberia' High
..." (Frank Capra, The Name Above the Title, 6)
"When my first book, America, America, was
published, on the dust jacket there was a quote
from James Baldwin, 'Gadge, baby, you're a nigger
too."' (Elia Kazan, A Life, 43)

1 This article will focus on two American film-makers who have seldom, if ever, been compared by American and European critics, Frank Capra and Elia Kazan. Yet one only has to glance at their autobiographies, published respectively in 1971 and 1988, to see that in spite of their success in Hollywood, both film-makers shared the experience, the aspirations and the frustrations, of millions of second-generation Americans, and never quite shook off the sense of being outsiders in a culture dominated by Anglo values. ${ }^{1}$

2 Capra was six when his Sicilian parents received a letter from a friend writing on behalf of his older brother, who had gone to the United States, and who encouraged them to join him in California. They did, and settled in a suburb of Los Angeles. Kazan was four when his Greek parents decided to join his uncle Joe, who had crossed the Atlantic and set up a rug-cleaning plant in New York. Both men had to struggle hard to rise, not exactly from rags to riches, but from the obscurity of a hyphenated American's life to stardom, celebrity, and wealth; yet both men saw themselves all their lives, in spite of their success, as outsiders; and both constantly hesitated between the desire to adjust, which implied rejecting their native Mediterranean culture, and the pull of old native traditions. In 1977, Capra belatedly revisited the Sicilian village of Bisacquino, which his family came from, while Kazan decided much earlier, in 1962, to tell his uncle's odyssey, first in a text which was half a novel, and half a script; then in a film whose shooting led him to go back to his native village and to his long-forgotten 
relatives. The novel and the film were entitled America, America. The film was a flop in the United States and, interestingly, a success in Europe.

3 Here are two passages from Capra's The Name Above the Title and from Kazan's A Life. The first extract is the beginning of Capra's preface to his autobiography:

I hated being poor. Hated being a peasant. Hated being a scrounging newskid trapped in the sleazy Sicilian ghetto of Los Angeles. My family couldn't read or write. I wanted out. A quick out. I looked for a device, a handle, a pole to catapult myself across the tracks from my scurvy habitat of nobodies to the affluent world of somebodies. ${ }^{2}$

The second extract is Kazan's account of his graduation at Williams College:

I walked into Chapin Hall with my fellow seniors for our final ceremony, sat with them shoulder to shoulder, and wanted what they had: their style, their looks, their clothes, their cars, their money, the jobs they had waiting for them, and the girls they had waiting for them. I wanted all that, and I wanted it soon. Every time I saw privilege from then on, I wanted to tear it down or to possess it ... I wanted the full rewards of the system I'd been on the outskirts of for four years, the rewards I hadn't had. I wanted ... to take over. ${ }^{3}$

5 "I wanted out." "I wanted ... to take over." What first strikes the reader is the similarity of the two men's responses to their status as outsiders-a complex mixture of anger and shame which leads to a frantic need to forget their ethnic origins and force their way into the dominant culture. The differences between the two testimonies are not quite as obvious. Capra writes about his childhood, in an ethnic ghetto where he was selling newspapers not to succeed, but to scrape by. His parents were peasants from Sicily, who were trapped in the city. His main urge was to escape this ghetto, to get "across the tracks" by any means - which he did first through study (he went to high school, and was accepted in a technological college), then by getting menial jobs in Hollywood studios. After this he was able to rise from such jobs to the position of assistant director, then of director. Kazan writes about his student years, and the fact that he became a student in an Ivy League university is enough to show that he came from a different background-that of small shop-owners who hoped to make good, and who did before the Crash of 1929 ruined their prospects. Kazan's problem was not his distance from, but his closeness to, the WASP elite with which he had rubbed shoulders for four years, waiting tables to pay for his fees, serving his patrician fellow-students in silent anger. Paradoxically, this did not make his integration easier or faster than Capra's. After college, he too had to accept all kinds of odd jobs, not in the cinema (he lived, remember, over three thousand miles from Hollywood), but in the theatre, which he had chosen against his father's will. Traces of this early career survived for decades: his nickname, which stuck to him all his life among friends, was Gadge, i.e. the guy who always finds a gadget to solve small technical problems.

6 What brings those two accounts together is the outsider's syndrome, the fury at being, as Capra puts it, on the wrong side of the tracks, or, in Kazan's words, on the outskirts of the system. In both cases, this fury is fed by a feeling which is both classconsciousness and ethnic awareness. Note that Capra hates not only being poor, but being a peasant. Kazan does not put it quite in the same way here, but he does a little earlier: when his father and mother left abruptly before the end of the commencement ceremonies, he remembers with some confusion that he was relieved: "I'm ashamed to say I was embarrassed by their appearance and eager to have them gone. I wanted to be alone and to jump into the swim with the Anglos." 4 
7 A comparison between the two life histories is complicated by the fact that Capra's and Kazan's autobiographies offer very different self-images. The aggressiveness which is betrayed, or rather flaunted, by Kazan's account of the Williams graduation simmers in every page of the book, and erupts in a number of candid confessions, while the tone of Capra's first paragraph is strikingly unrepresentative of the book as a whole. His early frustrations are quickly disposed of, and he focuses on his upward course, on the tricks he used to force his way into the Hollywood studios, then to establish himself as a director and to secure the actors' confidence. Kazan's persona is that of a heavy, Capra's that of a good guy, and most critics went along with this, just as they "bought," to use an Americanism, what came to be called "Capra-corn"-inspiring vacuities about democracy, patriotism, loving your neighbour, and Christmas. But in 1992, Joseph McBride published a biography which he entitled The Catastrophe of Success, and which was based on extensive research, including lengthy interviews with the director, his relatives, his friends, and his professional acquaintances. McBride was not content to consult Capra: he checked the accuracy of his statements, even when they differed from the autobiography, so that we often have three accounts of the same event-that of the autobiography, that of the interview, and that which emerged from McBride's findings. The gap between these three narratives is staggering. The project of Richard Schickel, Kazan's biographer, contrary to that of McBride, was not revisionist (or if it was, it rather went in the other direction-trying to tone down Kazan's ruthless accounts of his personal and professional life, even when the issue was his reasons for naming names). Now if Capra's The Name Above the Title is strikingly different from Kazan's A Life, McBride's X-ray images, as we shall see, are much closer to the latter's confessions.

8 In his autobiography, Capra keeps extolling his parents' courage, which enabled them to survive in a hostile environment. He describes them as illiterate peasants and remembers his "traumatic shock on learning that not one of [his] peasant clan could read." And he adds: "And now I knew that peasants were poor and had to work like beasts because they were ignorant. That thought must have burned itself into my child's mind; I never forgot it, never lost my resentment against it." ${ }^{5}$ Hence, he concludes, his "later mania for education" as the only way out of the ghetto, and his constant struggle with his parents to go to school (which was exasperated by the invidious comments of the "Sicilian women of the neighborhood"):

To my family I was a maverick. I was jeered at, scorned, and even beaten. But I wouldn't leave school. That meant not only paying for my own education, but putting some change in the family kitty as well ... Oh, I loved my family and respected their thrift. But how could they know what I knew, that sure I was born a peasant, but I'd be damned if I was going to die one. ${ }^{6}$

Here a precarious balance is achieved between rebellion and respect, both leading to a very effective form of self-aggrandizement (note the hint about the money he gave his family). Meanwhile, his parents worked themselves to death, which, in his memory, triggered off conflicting emotions:

With a child's eye I used to look up at Mama. There she was, standing all day on blistered feet I knew wouldn't heal; standing all day in the miasmic steam of the olive plant-ten hours a day for ten dollars a week ... I'd look up at Mama's face, her strong peasant face, now wet with strain; nodding, nodding, nodding; a robot chained to the monster's rhythm ... And Mam looked like a witch to me. A Halloween witch. And I'd run off, and bite my lip, and clench my fists, and curse America. 
The "strong peasant face" is Capra's loving remembrance of his mother as he looks back on her, while the "Halloween witch" is the child's spontaneous response to a traumatic sight-that of a human being who has been turned into a robot or a beast by the assembly line. After which he describes the ordeal of his father's work at the local

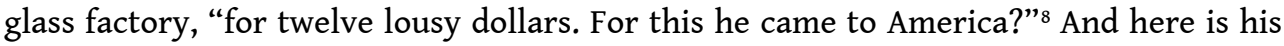
account of his own efforts to earn some money:

In town I sold papers to big fat businessmen, wearing big fat coats; big fat necks overflowing tight white collars; entering big fat limousines through doors held open by big black chauffeurs. How I resented them. 'All going home to big fat dinners,' I'd think to myself. 'Meat they'd eat. Big fat meat. Damn them!'

11 The physical appearance of these "big fat businessmen" may help us to understand Capra's choice of Edward Arnold for the role of the arch-villain in the great films of the 1930s (Anthony Kirby, Jim Taylor, J.B. Norton). Such outbursts which, let me emphasize once more, are rare in the autobiography, betray something like a return of the repressed for the wonder boy of Hollywood who constantly describes himself as a Horatio Alger self-made hero. ${ }^{10}$

12 The passage at hand is actually a good example of the way Capra, in the autobiography as in a number of his films, turns an ordeal into a providential event. The above quotation opens chapter thirteen of the book. It is preceded by two sentences which radically alter its ideological purport: "My first forty years were over. Forty years that could only happen in America; that began with a childhood hate for America. " ${ }_{11}$ We have here the beginning of an edifying story which could be summed up as follows: the immigrant's son is estranged from his parents, whom he sees as beasts of burden, and develops a hatred of the country which is responsible for this; he also develops an irresistible urge to escape from this trap through study and self-help. He does escape, and realizes that what he saw as exploitation was only the first step to the self-made man's success. And becomes a patriot. Happy ending of Lucky Frank.

13 McBride's book helps us to draw the line between lived experience and what he calls "fairy-tale." First of all, if Capra's parents were peasants, his mother was not illiterate. They settled in a multi-ethnic area which was far from being an Italian ghetto. His mother did object at first to his going to school, but when she realized he did well there, she became resigned to the fact, and far from giving part of his meagre salary to his family, he received financial help from his parents and from his sister. His mother did drudge throughout his youth, but his father did not spend long at the glass factory, and was constantly rebuked by his wife for his laziness and improvidence. His mother, whom he canonizes ("How strong she was, how unafraid, how real ..."), responded to her husband's death in a horrible accident (he was mangled and cut in two by a motor pump) without undue emotion. When her daughter said "Don't you want to cry?", she answered: "He is your father. If you want to cry, cry. He made me cry enough when he was living." ${ }^{12}$ It is as difficult to reconcile such raw facts with the overall pattern of the autobiography as it is to deal with the abrupt reversals of Capra's film plots. Hence the strange effect produced on the reader by McBride's book-how much of Capra's account is genuine, and how much is it "fairy-tale"? Let us be content to note for the time being that Capra did sell newspapers as a young child, that he did have to find work throughout his student years, and that he was excluded from the social life his better-off friends could enjoy. 
14 Kazan's account of his childhood and youth is at the same time more complex and more straightforward. His parents, he reminds us, came not from Greece, but from Anatolia where their status was both comfortable and precarious. When he returned to his native town in 1962, he met his cousin who was "the office-manager, the treasurer, the diplomat, the administrator of the sultan's staff, and highly regarded as such," but "his costume, while it was evidence of a higher capability than that of the native Turk who 'worked with his back,' also marked him and other Anatolian Greeks as targets in times of riot ..."13 Thus, what his father had brought with him to America was "the Anatolian smile" (which was the first title of the novel that preceded the film):

When Father had first come to America, he must have felt that he was still in a hostile and threatening environment-after all, he could not speak the languageso he continued to behave in New York as he had among the Turks, guarding himself to be circumspect, always beyond criticism on the streets and in the marketplace, always ready with his smile of compliance ... He learned to survive by cunning, by guile, and by restraining his real reactions. ${ }^{14}$

His advice to his son aimed at instilling in him the same cautiousness: "Mind your own business' and 'Don't start up arguments' and 'Walk away from a fight." ${ }^{15}$ But as soon as he was back home, the unctuous tradesman became a domestic tyrant, who terrified his children and his wife. Like Capra, Kazan was a brilliant pupil. Like him too, he was able to study thanks to the active support of his teachers-an experience which he must have remembered when he shot his first Hollywood film, A Tree Grows in Brooklyn. One of these good fairies, who had taken a liking to him, "conspired" (his word) with his mother, without his father's knowing it of course, to make it possible for him to be accepted at Williams College. Kazan offers an explanation for this in his autobiography: "I became her special child. Perhaps I represented what she thought she might have been if she'd not been swallowed alive by a marriage." ${ }^{16}$ When Athena Kazan told her husband, he knocked her to the ground. This was only the first of several episodes during which Kazan himself received the unflinching support of his mother, whom he idolized-another similarity with Capra, although the two women were obviously as different as their husbands. George Kazanjoglou wanted his oldest son to take over the family shop, and tried very hard to initiate him to the trade, all to no avail: "Father referred to me as 'Hopeh-less case!' I said nothing. I was learning to take punishment without defending myself or fighting back. I still do that." ${ }^{17}$ Later, when Kazan decided to join the Yale Drama School, his father's only comment was: "Didn't you look in the mirror?" And here is Kazan's comment on the comment: "I would resent that for years, just as he resented for me walking away from him when he needed me in his store. ${ }^{18}$

16 Thus Kazan, like Capra, rejected, or tried to reject the family heritage, which in his case was embodied by his father, while in Capra's case it was rather the mother, supported by the "Sicilian women of the neighborhood." As my first two quotations unmistakably show, however, both men found it impossible to escape their status as outsiders. McBride reminds us that, for Capra, "sixty years later, the hurt was still fresh when he told in his autobiography of being rejected from Los Angeles High because he was regarded as 'riffraff' and being sent to Manual Arts [another school] to join the other "rejects." 19 Those of his friends that McBride was able to interview were even blunter:

I don't know that anybody liked him. He was ostracized; people never invited him anywhere. Because he was a foreigner, they didn't think of including him in their parties. He was a nice boy. He was just a terrible wop. ${ }^{20}$ 
17 Although Capra seems to have been relatively popular in college, he remained the Italian kid who waited tables, and he retained the wop stigma after college: an assistant director he met in 1928 remembered that "he looked like a young punk trying to get into the business." 21 Capra too keeps describing himself as a "peasant," keeps reminding his reader that the uncouth head of Columbia for whom he worked, Harry Cohn, called him "little Dago" whenever he wanted to make him mad, that is, frequently. Naturally enough, this sense of exclusion led to an inordinate desire for power, and an inordinate vulnerability, the two sides of his character becoming prominent alternately in the autobiography. The Name Above the Title could be described as an unusual success story where every triumph is followed by a fall, which usually takes the form of exclusion. Frank graduates from college, enlists in the army, only to find himself jobless, and ridiculed by his illiterate relatives. He succeeds in winning Mack Sennett's confidence, until he clashes with the boss and is fired. Later, he becomes a director, but his first film is such a flop that he must revert to his earlier job as gag-man, and receive the gibes of his former colleagues. Even his greatest triumphs can turn into nightmares, as when Mr. Smith Goes to Washington is shown to the Washington press corps and the members of the Senate, and creates uproar in both groups. Here again, it is tempting to compare such ups and downs with the bumpy course of his protagonists: Deeds is hurtled from the fairy-tale experience of the "Cinderella man" to the ordeal of a trial in which evidence is publicly exposed of his manic tendencies; Smith is catapulted from the enviable position of junior senator to that of a pariah, and Doe goes through an even more excruciating experience when he is described as an impostor and a fraud before the immense crowd of his followers. As McBride suggests, the obsessive recurrence of such situations in Capra's films suggests a unique mixture of guilt (success cannot be deserved, it must be stolen somehow) and resentment (when success suddenly escapes him).

18 Kazan was much more aware than Capra of his need for integration, of his failure to satisfy it, and of his inability to shake off inherited attitudes. He puts it squarely. First, the goal, which implies rejecting one's ethnic roots: "What did I want of life? Nothing noble. But, passionately, to be an American, to have what Americans had, a daily life like theirs, to be accepted by them, to enjoy what they were enjoying ..." ${ }^{22}$ Then, the means, which are the old Anatonian tricks: "I didn't recall it then, but I do now, a favorite phrase of my father's, Guzumuz yok, which is Turkish for 'We have no eyes.' And that means: We do not feel because we do not see slights, insults, and provocations. That is how we stay alive and continue here.' At Williams I survived by guzumuz yok." 23 Kazan is also much clearer than Capra on the frustrations bred by this constant holding in:

I remember wondering what the hell was wrong with me anyway. My looks? My goddam foreign looks? Those Anglos making the choices, what did they think? That I was a Jew boy? Yes, I looked like one. Was that it? ... Or was it something about my character? Was I clearly a freak of some kind?

I never found out ... I began to exercise violence in daydreams and in impulses that I thwarted ... From that week in 1926 on, I knew what I was. An outsider. An Anatolian, not an American. ${ }^{24}$

What is most striking here is the spontaneous identification with "a Jew boy ..." ${ }^{25}$ One page later, Kazan reminds us that on the dust jacket of his first book, America, America, was a quote from James Baldwin: "Gadge, baby, you're a nigger too." And he adds: "At Williams during those years, I was a nigger too." ${ }^{26}$ Two interesting statements, when we 
remember that his post-war film career began with a film on anti-semitism, Gentleman's Agreement (1947), and a film on racial prejudice in the South, Pinky (1949). This ought to be contrasted with Capra's almost total indifference to ethnic issues (he did approach racial issues very obliquely in The Bitter Tea of General Yen [1932]). Capra's heroes, at least those who captured the interest of spectators, are sublimated images of his own aspirations: small-town, true-blue Americans-Gary Coopers and James Stewarts. McBride suggests an explanation for this: "Though he managed to escape the neighborhood, Capra could never escape a feeling of exclusion from mainstream American society, and in later years he came to view those who had not escaped, black and Italian alike, with an unconcealed contempt." ${ }^{27}$ Besides, on the rare occasions when immigrants appear in his films, they are not only confined to marginal roles, but reduced to stereotypes-see the farmer who offers Deeds a sandwich when he is preparing to deal out his fortune-a perfect illustration of his later profession of faith during the trial (he is one of those who need a hand because they cannot make it) or, in It's a Wonderful Life (1946), the character of Giuseppe Martini whose thick Italian accent and stereotyped exuberance are offered to the spectator as evidence of touching inefficiency (shades of Capra's father?). The deserving poor are not necessarily liable to achieve the self-sufficiency that Longfellow Deeds and George Bailey so powerfully embody.

Beyond such obvious differences, a parallel reading of the two autobiographies, and of the two biographies, encourages one to have a closer look at the treatment of the related themes of family and exclusion in the films of the two directors. From A Tree Grows in Brooklyn (1945) to Splendor in the Grass (1961), America America (1963), and The Arrangement (1969), Kazan's protagonists are caught in two concentric circles in which they are both imprisoned and excluded: that of the family, whose constraints, taboos, prohibitions are seen as obstacles to growth, creativeness, opening out; and that of society which echoes and amplifies these girdles. Even in On the Waterfront (1954),a film which does not deal explicitly with the family, Terry's relationship with his brother is closely connected with his relation to his adoptive father, Johnny Friendly, and his feeling of impotence is inseparable from these two links. Stavros, the protagonist of America America, escapes from the sterilizing control of his father only to fall under the sway of a succession of foster-fathers or father-figures, from his cousin the carpetdealer to Garabet the revolutionary, then to Alebo the carpet "king," and finally to the good-natured, but crafty padrone who helps him usurp the identity of his deceased friend, Hohannes.

21 None of Capra's films, however, deals explicitly with the family. The film which comes closest to doing so is It's a Wonderful Life, which came out a year after A Tree Grows in Brooklyn and contains a number of similar themes (the opposition between the individual's dream of accomplishment and a constricting environment, the constant pressure of fate on a humble, noble life, the temptation of despair and the final triumph of hope, all of which are crystallized by the Christmas magic). But Capra's previous male protagonists are somehow free from family ties, from the cynical, jaunty journalist of It Happened One Night (1934) to the small town character of Mr. Deeds Goes to Town (1936), the lone boy ranger of Mr. Smith Goes to Washington (1939), and of course the ex-baseball star turned tramp of Meet John Doe (1941). You Can't Take It with You (1938) is not really an exception to the rule, since the protagonist seems to share only one trait with his family-screwball eccentricity- and since the said family is in fact a 
community of harmless crackpots. Thus one is tempted to say that Capra eschewed precisely what Kazan decided to confront. ${ }^{28}$

22 I have been struck by two other differences. The first regards the sexual problems bred by ethnic frustrations, which are extensively, sometimes complacently dealt with by Kazan-he explicitly attributes his "obsessive attraction to other men's women" to his pent up bitterness, ${ }^{29}$ and notes that his indifference to small, dark-haired women didn't stop him from being sexually effective, while his passion for tall, blond-haired WASPs often led to embarrassing let-downs. He is also remarkably candid about the way he used his status as director to "bang" (his word) Anglo girls, preferably married. It would be interesting to analyse the refraction of these compulsions in his films. Two instances come to mind: the character of Blanche in A Streetcar Named Desire (1951) and Carroll Baker's character in Baby Doll (1956)-both Southern "ladies," that is quintessentially Anglo, bothunreachable icons of purity and lasciviousness, whom Kazan, with his usual bluntness, would certainly have called cock-teasers. Interestingly, Blanche inspires an ethnic character with brutal desire while she fills a native-born American with quasi-religious reverence. In an almost symmetrical pattern, Baby Doll teases her Anglo husband and connives with Silva Maccaro, a "Sicilian smoothie" (to quote Richard Schickel) to drive him mad. At the opposite end of the spectrum, we find Terry's relation to Edie in On the Waterfront. Although both belong to the Irish-American community, the very choice of Eva Mary Saint to play Edie allows us to see her as another embodiment of Kazan's immaculate, unreachable blondes. The fact that she has been protected (by her education in a Catholic school) from the violent realities of the docks allows us to see the relationship as a strikingly different variant of the same theme.

23 Contrary to Kazan, Capra is almost entirely silent on the subject of sex, and prefers to insist on the longevity of his second marriage, after justifying his separation from his first wife by describing her as an alcoholic. McBride's research, however, shows that he did have his hang-ups, but chose to ignore them and invest all his energy in his work. First of all, he failed to win the "nice" Anglo girl he was madly in love with-she married another student, from her own background, and the hurt was so deep that he did not mention the episode in his autobiography. McBride also shows that his (Anglo) first wife did drink, but that her drinking took place not as a cause, but as a (probable) consequence of her husband's work-alcoholism. Sex is no more present in Capra's films than in his autobiography-several of his male protagonists fall in love with "ladies in distress," and when they realize the object of their cult has connived in their downfall, sex has nothing to do with the sense of betrayal that overwhelms them. As for the ethnic dimension of love relationships, it is entirely lacking; but just as Deeds's or Smith's rural naivety is not very remote from the immigrant's helplessness in the face of an unknown culture, just as their position as outsiders makes both easy targets for con-men of all kinds, Deeds's love for Babe Bennett or Smith's infatuation with Senator Paine's daughter are not markedly different from young Capra's or young Kazan's attraction to sophisticated, blonde, Anglo girls.

24 The second difference regards the two film-makers' rediscovery of their native land. Kazan was 53 when he went back to Turkey and Greece to shoot America, America, and recovered the amputated part of himself that he had missed all his life. In his later years, he wrote a sequel to America, America, thought of settling in Greece, which was the subject of his last novel, Beyond the Aegean. Capra, conversely, lost all interest in his 
Sicilian roots, beyond his usual boast about his "peasant" staying power. He went to Italy several times, but did not go to Sicily until 1977 (he was 79), and even then tried (unsuccessfully) to skip his native town. He later confessed to McBride: "I felt nothing. Who the hell cares where you were born? That town meant nothing to me. You know that colored guy, that Roots thing? He's full of shit. I hate the word 'roots.' People are so proud of their roots it's sickening." ${ }^{30}$ The dark side of this challenge appears in an interview he gave to an Italian film historian, Gian Pietro Brunetta, in the late 1980s: "I have no identity because I cancelled my identity. I have no fatherland." ${ }^{31}$

I hope to have shown that a parallel between these two "ethnic" American filmmakers, incongruous as it may seem, is not without relevance. Kazan's career began two years before Capra's last masterpiece came out. This would not be enough to bring them together, if one did not find a kind of covert dialogue between their autobiographies, and a number of surprising, puzzling echoes between their films. ${ }^{32}$

\section{NOTES}

1. The term "second-generation" may seem inappropriate, since both directors were born in Europe, but they came to America at such an early age that their experience was indeed that of second-generation Americans.

2. Frank Capra, The Name Above The Title: An Autobiography (New York: Vintage, 1985, first pub. in 1971), xi.

3. Elia Kazan, A Life (New York: Knopf, 1988), 44.

4. Ibid., 40.

5. Capra, The Name Above The Title, 3.

6. Ibid., 6 .

7. Ibid., 236.

8. Ibid., 237.

9. Ibid.

10. On Capra's heavies, see my "Frank Capra et la ploutocratie: les séductions de l'antiAmérique," in L'Antiaméricanisme/Anti-Americanism at Home and Abroad (Aix-en-Provence: Publications de l'Université de Provence, 2000), 117-34.

11. Capra, The Name Above the Title, 236.

12. Joseph McBride, Frank Capra: The Catastrophe of Success (New York: Simon and Schuster, 1992), 84.

13. Kazan, A Life, 642 .

14. Ibid.

15. Ibid., 11.

16. Ibid., 26.

17. Ibid., 30.

18. Ibid., 12. For a more detailed analysis of family links and family conflicts in Kazan's childhood and youth-and his oblique treatment of these themes in his most autobiographical film, see my "Elia Kazan, le retour: la quête du pays dans America America," in Bulletin du CICLAHO, 3 (2003): 147-60.

19. McBride, Frank Capra,50. 
20. Ibid., 54 .

21. Ibid., 188.

22. Kazan, A Life, 28.

23. Ibid., 42.

24. Ibid., 41.

25. We find a number of similar references in Kazan's autobiography and in his interviews with Michel Ciment. See Michel Ciment, Kazan on Kazan (New York: Viking Press, 1974).

26. Kazin, A Life, 43.

27. McBride, Frank Capra,36.

28. I have focused here on the specificity of each director's approach to the theme of exclusion. It goes without saying, however, that the experience to which both men reacted was very similar, and that Capra, like Kazan, derived from this experience an immoderate need to prove himself, together with an immoderate fear of failure. Interestingly, both autobiographies describe their authors' careers as a succession of ups and downs, of dizzying successes and abysmal disasters.

29. Kazan, A Life, 43.

30. McBride, Frank Capra,11.

31. Robert Sklar and Vito Zagarrio, Frank Capra: Authorship and the Studio System

(Philadelphia: Temple University Press, 1998), 47.

32. One final instance, which has nothing to do with ethnicity, but a lot to do with exclusion: I have always been convinced that the scene of America, America in which Stavros, now a rich heirto-be, offers a meal to his destitute friend is an echo of the more famous scene in which Longfellow Deeds invites the desperate farmer who threatened to kill him to share the meal he can no longer give to Babe Bennett. For another unlikely parallel, see my "Le retour du politique: L'homme de la rue (Meet John Doe) de Frank Capra et Sur les quais (On the Waterfront) d'Elia Kazan," in Trudy Bolter, ed., Cinéma anglophone et politique (Paris: L'Harmattan, 2007), 85-93.

\section{ABSTRACTS}

Frank Capra and Elia Kazan both came to the United States as children. From immigrant stock, each experienced the effects of being looked down upon as outsiders to Anglo culture. Based on the two men's autobiographical accounts, together with their films and biographical writings about them, this article examines the routes by which they sought entry into the dominant culture. This process would require the rejection, in each case, of part of his family heritage. It would lead to very different attitudes to ethnicity in their films: Kazan demonstrated interest in the subject, whereas Capra largely suppressed it. The article underlines other "covert dialogues" in the films directed by the two men. It shows that they most diverged over issues of sexuality and the later rediscovery of their ethnic roots.

\section{INDEX}

Keywords: Anatolia, Anglos, dominant culture, ethnic frustrations, exclusion, family, integration, outsiders, Second-generation Americans, sex, Sicily, WASP elite 
AUTHORS

YVES CARLET

University of Montpellier 3, France 